\title{
Censorship, Academic Freedom and Legal Regulation: A Bahamian Case Study
}

\section{Michael Stevenson ${ }^{1}$}

\begin{abstract}
This paper provides an analysis of a dimension of the legal environment within which academic freedom in The Bahamas was encroached upon by government agencies of The Bahamas exercising regulatory authority over the public viewing of a film. The analysis was conducted through an inquiry to determine whether the constitutional right of freedom of expression was violated when academicians, having organized a public study session relating to censorship, were prohibited from using footage from a banned film as part of their study session. The paper suggests that Bahamian courts, based on the analysis presented in the paper, would conclude that the regulatory actions of the administrative agency in question constituted a breach of the constitutional right of freedom of expression.
\end{abstract}

\section{INTRODUCTION}

In April of 2006, the Bahamas Plays and Films Control Board (the Board), an administrative authority established under the Theatres and Cinemas Act (1975), refused local theatres permission to show a film about a love affair between two men, after having initially approved the film for showing. The requirement that all public performances of a film be approved for showing by the Board is found in s. 6(1) of the Theatres and Cinemas Act of 1975, which reads: "Subject to the following provisions of this Act, no public performances or exhibition shall be given otherwise than in circumstances approved by the Board pursuant to regulations made under subs. (2)." Public performance or exhibition, in accordance with the Act, means a "performance of a play, or, as the case may be, an exhibition of a film, in a public place; or a performance of a play or ...exhibition of a film which the public .....are permitted to attend ..." The meaning of "public place" in the Act is defined broadly with reference to s. 4 of the Penal Code (1927). Pertinent regulations made under s. 6(2) of the Theatres and Cinemas Act (1975), for the purposes of this inquiry, are contained in the regulations that require the Board to classify films approved to be shown in order to regulate the conditions under which various age groups are entitled to view a film. More important is the subsidiary censorship regulation that requires the Board to withhold approval of a film, or any part thereof, "which in the opinion of the Board depicts any matter that is against public order or decency or the exhibition

\footnotetext{
1 Michae Stevenson, School of Social Sciences, The College of The Bahamas, P.O. Box N-4912, Nassau, Bahamas.
Acknowledgments: The author was one of three academics responsible for organizing a public study seśsion on the topic: State, Church and Human Rights: The Politics of Censorship. The other organizers were Dr. Ian Strachan, Chairperson of the School of English and Ms. Jessica Minnis, Chairperson of The School of Social Sciences of The College of The Bahamas. Presenters at the study session included the author, Dr. Nicolette Bethel, Dr. Ian Strachan, Dr. Kirkley Sands, and Ms. Patricia Glinton-Meicholas. The paper represents a work in progress towards a longer essay on law, activism, censorship, rational speech situations, and the post-colonial setting. It was delivered at a study session at The College of The Bahamas entitled State, Church and Human Rights: The Politics of Censorship. E-mail: mstevenson@cob.edu.bs
}

How to cite this article in APA (7th ed.) style: Stevenson, M. (2008). Censorship, academic freedom and regulation: A Bahamian case study. The College of The Bahamas Research Journal, 14, 19-27. https:// doi.org/10.15362/ijbs.v14i0.100 
or performance of which would for any other reason be undesirable in the public interest" (Theatres and Cinemas (Censorship) Regulations, 1976, s. 6(1))

In response to the huge stir generated by the banning of the film in question, academics in the School of Social Sciences and the School of English Studies at The College of The Bahamas, began to prepare a free, public study session to examine the topic: "Church, State, and Human Rights: The Politics of Censorship”. In a rationale provided to senior administrators at their institution, they asserted that the study session would be geared towards "informing the public of some of the important constitutional, political, and national developmental issues and problems surrounding the work of the Bahamas Plays and Films Control Board" (Stevenson, Minnis, \& Strachan, personal communication, May 10, 2006). In their rationale they also outlined how the study session would be organized: a panel of academic presentations on the topic of the study session would proceed after short excerpts from the banned film were shown.

On the second evening of the study session, a full showing of the banned film that had stirred such a controversy would be shown, to be followed by a question-and-answer period with the participants of the study session. With all of this information included in a letter to the Chairperson of the Board, the academics organizing the public study session applied for permission from the Board to show the banned film to an audience of persons aged eighteen years and older.

Two related questions need to be answered at this juncture. Firstly, why did the organizers of the planned study session want to show excerpts from the banned film at their study session as originally conceived? Secondly, why did the study session organizers apply for permission from the Board to show the film in public knowing that the same Board had earlier refused to approve the film for public viewing?

To the first question, the response (known by the author because he was one of the organizers of the study session) is that as educators and organizers of the study session, the organizers knew that the banned film had created a learning opportunity for the community (the expanded classroom) to begin to examine the decision making process (inclusive of influencing factors) of an administrative body charged with the task of regulating public consumption of plays and films. They had anticipated that by showing excerpts from the banned film, along with clips from approved films, those attending the study session would begin to inspect and question closely the criteria used by the Board in reaching its decisions, the Board's interpretation of such criteria, and the consistency of the Board's decision-making.

The planners of the event understood that showing actual footage of both banned and non-banned material would make the study session more vivid and real than simply having a "chalk and talk" session - the use of visual aids being a standard tool used in learning. At the same time, they did not see why adult members of the public should be deprived of the educational benefit of studying along with other adults engaged in the pursuit of information relating to the practice of censorship in The Bahamas, or be deprived of the views of academics on the matter. After all, they maintained, The College of The Bahamas was a public institution, and as educators paid from the public purse, they believed the "classroom" extended beyond the "walls" of the conventional site of learning. Moreover, it was clear to them that the community expected The College of The Bahamas to play a public educational role in society and that it had done so on many occasions in the past. They had to look no further for evidence of this understanding than their own professional evaluation categories requiring community service and the long history of public seminars and colloquia conducted at their institution.

As for the question directed at the ostensible futility of applying for permission to show a film that had already been banned, the organizers' response held fast to the view that it would be absurd if a decision by the Board to ban a film to be used in a certain public context meant that the same film could never be shown in any other public context. In their view, which they were certain had the backing of common-law precedent, if the Board were ever to not exercise its discretionary powers when a new application to approve a banned film was presented to it (on the basis that the old prohibition automatically 
applied to the circumstances surrounding the new application) then these actions of the Board could be subjected to judicial review on the ground that the Board had failed to exercise its authority as required of it, and thereby had exceeded its statutory powers. (Singh v. Chinilall, 1963) Further, they felt that if it were within the power of the Board to make such sweeping decisions to prohibit a film and not be duty-bound to reevaluate its decision upon the request of an applicant in circumstances different from those of previous applicants, films banned during a certain era, or for use in a certain context, like the film Jesus Christ Superstar that was banned in The Bahamas in the 70's, could legally remain automatically censored across changing social settings and into eternity.

All of these considerations pointed them towards the conclusion that a reasonable construction of the Theatres and Cinemas Act 1975 and the powers of the Board must be based on the assumption that Parliament had intended to create the possibility for the Board to review its own decisions when requested, especially those decisions that related to the banning of a film or play. And so, having assumed this to be one of the duties of the Board, the three College of The Bahamas academicians (the organizers of the study session) applied to the Board for permission to show the banned film given the changed circumstances that its public viewing at the study session would be for purely public educational purposes.

The Board's response to their application, via the Ministry of National Security, was that once a film was banned it could not be shown for public viewing. The response to the application submitted by the academics to the Board came from the Permanent Secretary of the Ministry of National Security. The response was addressed to the Acting President of The College of The Bahamas. There is evidence to suggest that the Board may have not exercised its authority in relation to the application and allowed the Ministry of National Security to make the decision. A clear line of judicial authority indicates that if this were to have been the case, the Board's abdication of authority in the matter would have amounted to an abuse of discretionary power by the Board. (See D'Aguiar v. Attorney-
General, 1962) For reasons already stated, the blanket decision of the Board suggested a complete failure by the Board to carry out its statutory duties, and, in the view of the organizers, made the Board's refusal easily subject to judicial review. Nevertheless, in their view, the more pressing concern was to assume that the Board had exercised its discretion and to then question the constitutionality of the Board's refusal to allow them to show the banned film as part of their planned study session.

\section{FREEDOM OF EXPRESSION}

By virtue of Article 23 (1) of The Constitution of The Bahamas (1973), freedom of expression, defined in the article as the "freedom to hold opinions, to receive and impart ideas and information without interference, and freedom from interference with [one's] correspondence," is protected from being hindered.

As with most of the individual rights and freedoms under the Constitution of The Bahamas and other Commonwealth Caribbean constitutions, the protection of freedom of expression offered by the Constitution is not absolute. In certain circumstances, defined somewhat vaguely in the Constitution, freedom of expression can be restricted if the restriction is the result of the operation of a law or action done under the authority of law that is "reasonably required" in the interest of public ends itemized in Art. 23; with the proviso that the said restriction must be also "reasonably justifiable in a democratic society.”

The first question, then, that would have to be answered as part of an inquiry into the constitutionality of the Board's decision, is whether the freedom of the organizers of the study session to impart ideas free from interference was hindered by the Board's decision not to allow the banned film to be used as part of the study session. This can only be answered by discerning what ideas the organizers were hoping to impart by the showing of the banned film at the study session and whether the decision of the Board hindered that process of transmission. As already stated, it was thought by the organizers that showing excerpts from the banned film, along with clips from approved films, would have provided those persons attending the study session 
with the opportunity to begin to closely inspect and question the criteria used by the Board in reaching its decisions, the Board's interpretation of those criteria, the consistency of the Board's decision-making, and the social and political forces shaping both these matters of interpretation and consistency. What the educators organizing the event were hoping to impart to the public in attendance, then, was a critical framework and the opportunity to apply that critical framework to banned material as well as material that had not been banned.

It was also understood by the organizers of the study session that the various academic presentations arranged by them would impart ideas pivotal to the formation of this critical framework and its application. The organizers of the study session had hoped that showing of the banned and approved clips in the context of the scholarly presentations they had organized and their anticipation of the interactions of participants, would have conveyed the critical framework they hoped would have been adopted by the study session participants. Additionally, none of them was apologetic for wanting to impart this critical framework for analyzing the work of the censorship board within a context that by convention had always been linked to the democratic participatory duties of the citizennamely, that of the public forum.

What the study session organizers had hoped to achieve with the showing of the excerpts from the banned film, in the context of the study session as a whole, was thrown into doubt by the actions of the Board. The visuals would have allowed precise comparisons between banned and nonbanned films. Greater insight into the critical issues generated by such comparisons would have arisen had clips from the banned film been used. Generally, the Board's decision to prohibit the use of the banned film at the study interfered with the formation of the critical insight the organizers had hoped to impart at the study session.

Of course, all the arguments advanced here that explain how the organizers' rights to transmit ideas and information were hindered also explain how the rights of participants at the study session to receive ideas and information were also hindered. In addition, they stand as a refutation of the argument that the availability of the banned film on video, DVD, TV, etc, for private use meant that the banning of the public use of the film did not hinder freedom of expression. As already explained, the study session had been organized to impart a critical perspective regarding the work of the Board, and the film would have been used as a learning tool.

Establishing that an apparent hindrance to freedom of expression was caused by the Board's decision would constitute only the first part of the test to determine whether freedom of expression had been infringed by the Board. The right to freedom of expression is not absolute. Under Art. 23 of the Constitution, limitations placed on freedom of expression will only be considered constitutionally valid if the courts determine, as part of the overall constitutional test contained in Art. 23, that limitations arising as the result of a law, or actions taken under the authority of law, are considered to be reasonably required in the interests of the enumerated public interest grounds that fall within Art. 23. Additionally, for the limitation to be considered valid, the courts must determine that the reasonably required limitation can be considered reasonably justified in a democratic society. The way that Art. 23 is worded and structured in the Constitution suggests that once the law being constitutionally challenged is regarded as reasonably required then any actions taken under the authority of that law will be considered to be reasonably required.

Legal certainty, the test of reasonable requirement, and the test of reasonable democratic justification constitute the three elements of the overall test to determine the constitutional validity of a limitation placed on freedom of expression.

\section{Legal Certainty}

The requirement of legal certainty for all limitations placed on fundamental rights is an expression of the Rule of Law doctrine that opposes the arbitrary curtailment of liberty. Straightforward interpretations of Art. 23, and all other articles in the Bill of Rights of the Constitution, maintain that limitations placed on a fundamental freedom must be contained in a rule, or based on a decision made under the authority of a rule. The rule itself must be crafted with sufficient certainty and authority for it to be 
considered a rule of law. (deFreitas v. Permanent Secretary of Agriculture \& Fisheries, Lands and Housings and Others, 1998)

Section 6(1), which places in the hands of the Board the power to prohibit a film or play from being exhibited to a public audience prior to its release to the public, arguably fails the legal certainty test. In the words of a prominent Bahamian constitutional law practitioner, the Board has been granted censorial powers under s. 6(1) to ensure public order and decency and to uphold public interest, but "no criteria [in law] has [sic] been set for the board to follow". (Mortimer, 2007)

The extremely wide and arbitrary powers given to the Board to determine what constitutes a threat to public order and decency, and to determine when the content of a play or film is undesirable in the public interest, fails to provide clear, certain, and predictable limits of freedom of expression relating to films and plays. Support for this approach to the problem can be found in Ontario's Court of Appeal decision in Ontario Film and Video Appreciation Society and Ontario Censor Board, 1983. It was held in this case that Ontario censorship powers limiting freedom of expression under the Bill of Rights in the Canadian Charter were unconstitutional as the censorship powers were not sufficiently specific for them to be regarded as being contained within a "prescribed law.”

Assuming that s. 6(1) would pass the test of legal certainty, the next step in the constitutional test would be to determine whether s. 6(1) could be considered "reasonably required" in the interest of an enumerated public interest within the article.

\section{Reasonable Requirement}

In Commonwealth Caribbean constitutional case law, it has been recognized since the Privy Council decision in Hinds v. The Queen, 1977 that enactments of Parliament under the legislative powers contained within Commonwealth Caribbean constitutions are presumed to be reasonably required in the interest of relevant enumerated public interest grounds. The presumption can only be rebutted if the court, considering the constitutionality of legislation, considers in no uncertain terms (notwithstanding the introduction of implied terms by courts attempting to save the legislation from constitutional challenge) that the allegedly impugned enactment is not reasonably required in the interest of a relevant enumerated public interest within the applied limitation provision of the Constitution.

The modern test in the Commonwealth Caribbean concerning what constitutes a law that is reasonably required in the interest of an enumerated constitutional interest (the rationality/proportionality test) is found in deFreitas v. Permanent Secretary of Agriculture \& Fisheries, Lands and Housings and Others, 1998.) According to this locus classicus on the testing of the proportionality of enacted limitations to fundamental freedoms, the following test of proportionality must be applied to determine whether an enacted limitation can be considered reasonably required:

Is the legislative objective sufficiently important to justify limiting a fundamental freedom?

Is the limiting provision rationally connected to the legislative objective?

Is the limiting provision no more than is necessary to accomplish the objective (i.e., is it excessive)?

Negative responses to any one of these questions would provide a court with sufficient justification to declare a limitation unconstitutional. A cursory analysis shows that the legislative objective of the Theatres and Cinemas Act (1975) and, specifically, s. 6(1) of the regulations made under the Act, would be considered by Caribbean courts sufficiently important to justify limiting the right to freedom of expression. Rangarajan $v$ Jagjivan Ram, 1990 is one in a plethora of cases in the wider Commonwealth that support the proposition that "censorship by prior restraint is not only desirable but also necessary" (p. 417). Similarly, it is clear that the powers of the Bahamas Plays and Films Control Board under s. 6(1) of the regulations are rationally connected to the prior restraints objective of the principal Act. The question whether the powers under s. 6(1) are excessive raises the most concern about the constitutional validity of these powers, that is, 
whether these powers would be considered reasonably required.

The following analysis concerning the excessive nature of the Board's powers contained in s. 6(1) suggests that the issue of proportionality is linked to the test of legal certainty and the test of reasonable democratic justification. For a start, to the extent that s. 6(1) is considered excessive, the argument can be made it is because the provision lacks legal certainty. The more specific the criteria for the exercise of power contained in a provision, the more unlikely it is that it will be regarded as an overly vague provision that can give rise to the excesses produced by its application.

Concerning the latter linkage, the actual excesses produced by the discharge of powers under s. 6(1) can be assessed by considering the various ways in which the actions of the Bahamas Plays and Films Control Board offended the various aspects of the principle of democracy upon which the test of reasonable democratic justification is founded. And if the actions of the Board carried out under the authority of s. 6(1) constitute actions that cannot be regarded as reasonably justifiable in a democratic society, then this speaks to the excessive discretionary power contained in the provision itself and, thus, to its disproportional character when considering whether the provision itself passes the test of the reasonably required limitation. This is because under Art. 23 of the Constitution, for an enacted limitation of a fundamental freedom to be considered constitutionally valid, in addition to passing the test of proportionality, the enacted limitation and the "things done under the authority" of the statutory authorization must be shown to be reasonably justifiable in a democratic society. The point then to be emphasized here is that the proportionality test and the test of democratic justification are closely connected and integrated tests. Can s. 6(1) and, more importantly, the actions that were taken under the authority of this regulation be considered reasonably justifiable in a democratic society?

\section{Reasonable Democratic Justification}

Given the scope of what might be considered reasonably justifiable in a democratic society or not, it is reasonable to argue, were the Board's decision to have been constitutionally challenged, that the bulk of the court's creative energies and that of the lawyers involved in the case would have been taken up attempting to resolve the following question: is it reasonably justifiable in a democratic society for a censor board, acting under the authority that it did, to effectively prohibit academics from showing a banned film for the purpose of conducting a study session on the topic of censorship? In answering this question, two lines of argument will be used to suggest why the actions of the Board, in the context of the situation that has been described, should not be considered reasonably justifiable in a democratic society. By suggesting them, they become part of the legal context within which prior-restraints censorship of publicly exhibited films for adult educational purposes can be situated.

\section{ACADEMIC FREEDOM}

The first argument might be called the "academic freedom argument". This position advances the idea that the pursuit of truth, freed from the moral and political will of people in society, is a principle of utmost importance in societies that value democratic rule. It could be argued that this principle not only immunizes the place reserved for the academy in democratic society, but also wraps the press in its protective veil. Arguably, the principle forms part of a wider discourse that has prevailed with the rise of Western modernity. This discourse regards the pursuit of truth and power as mutually exclusive processes. Critics of this way of thinking point to the way that this discourse often obscures the way in which discourses of truth, and the institutions devoted to its production, are themselves inscribed within power relations and are themselves producers of power (Foucault \& Gordon, 1977). Still, the conventional understanding that power corrupts truth, that the academy-and more generally that rational speech itself as an engine of truth needs to be given a special and protected place in society free of political, social, and economic interference or forces of distortion-is an understanding that could be used to advance the argument that the Board's decision ran against a very hallowed principle of the modern democracy. Habermas's (1984) sophisticated defense of the possibility of 'speech situations' freed of the distorting 
influences of power provides strong support for this position.

For the academic freedom argument to be successful however, it needs to be coupled to another argument that emphasizes the position that, within a democratic setting although the academy is reserved a special and somewhat protected space to practice freedom of expression, that space should not be confined to the privacy of the virtual or non-virtual private classroom. The core question, in this regard, is this: to what extent does or should the privilege of academic freedom accompany the academy beyond the private classroom as the academy expresses its public role in society? The Ministry of National Security and the Bahamas Plays and Films Control Board were of the view that academic freedom operated only within the confines of the private classroom. (Swain, 2006) They pointed out that this explained their decision not to allow the showing of the banned film at the public study session. In a constitutional challenge to this reasoning, it would have to be shown that it is precisely in the academy's public role, or for that matter that of the press, where attempts at the formation of truth freed from the interference of power become so vital for a democracy. This line of argument is strengthened when the role of informed consent in, and for, a properly functioning democracy is fully understood. To this, the counter-argument could only be that in a democracy the value of academic freedom in the public sphere, for the purposes of creating informed consent, has to be balanced, on a case-by-case basis, against the possible harm caused in each such case to the public interest. The balancing-of-interests operation that such arguments would compel the judiciary to undertake, would require the judiciary to assess the specific public harm possibly caused by a specific public exercise of academic freedom functioning in support of the democratic process.

Given the analysis so far, it is difficult to imagine courts in The Bahamas placing greater value on protecting the public from a vaguely defined public-morality harm that might befall the public as a result of adults gathering publicly in the company of academics at a place of education to learn about censorship with reference to an acclaimed film that contained homosexual content than on protecting the principle of academic freedom and the function that it plays (or might play) in the processes of informed-consent formation within a democracy. Regarding the public-morality harm, one can only speculate that it might be suggested that somehow by showing banned footage involving homosexuality, in the context of an academic discussion about the rationality of the censorship process in The Bahamas, homosexuality was being endorsed as an acceptable practice in a society where it is regarded as morally offensive.

\section{RATIONALITY}

The second line of argument might be called the "rationality argument". It would advance the position that one of the ideas upon which a democracy is predicated is the notion that governmental agencies are accountable, and that governments must account for many things, one of them being the rationality of their actions and decisions when exercising statutory powers reposed in them by citizens through the legislative authority of their elected representatives. As part of that position, the claim would be made that irrational decision-making on the part of public agencies exercising discretionary statutory power is never reasonably justifiable in a democratic society. It would then be argued that the refusal of the Board to allow the showing of the banned film at the study session-the apparent encroachment upon freedom of expression-was an irrational exercise of discretionary power by the Board that was not reasonably justifiable in a democratic society.

One source of support for this line of argument could be gleaned from cases and principles of administrative law in the Caribbean and the wider Commonwealth that shows rather emphatically that no public authority exercising discretionary statutory power has the authority to exercise power in a way that is irrational. Courts have justified on many occasions their jurisdiction to intervene in cases involving the irrational exercise of statutory powers by an administrative agency on the ground that a reasonable way of construing the meaning of such powers is to assume that their authors intended for them to be rationally exercised. (Council of Civil Service Unions Minister for the Civil Service, 1984) It would be a novel line of argumentation, fusing principles of 
administrative and constitutional law.

But what would be the substance of the claim that the Board's decision was irrational? Simply this: if the study session, as originally conceived, had been conducted in the 'privacy' of the classroom with college students (some of whom would be beneath the age of 18) and the prohibited film had been used as a teaching aid, no authority could have legitimately intervened to prohibit the use of the film. In fact the Ministry of National Security indicated that this would have been perfectly acceptable (Swain, 2006). Yet given this fact, the Board maintained the opinion that for the academics organizing the study session to have shown the banned film at an academic study session for adults only would have been indecent and undesirable in the public interest. The potential absurdity created by this exercise of the Board's authority is self evident. And it would not be sufficient for the Board, in response to this argument, to have said that its authority did not extend into the private sphere. It is precisely because the Board had no authority to regulate in the private sphere what films minors or young persons view that makes it completely irrational for the Board to prohibit adults from publicly viewing films being shown for educational purposes.

A refutation of this position must assert a counter argument: that the general public is harmed when it learns that a film, with content thought to be morally damaging to society, has been shown to adults for educational purposes. As part of this riposte, it would also have to be contended and supported that-within the tight parameters of public adult education-society, or segments within it, would be more inclined to regard as acceptable the content of such a film as a result of it being shown. This line of reasoning would have to be built on the presumption that the general public, or segments of the public, could not differentiate between the moral implications of adults watching a film in public for educational purposes, on the one hand, and that of them watching a film for entertainment, on the other. Furthermore, such reasoning would have to presume that segments within the public, or the public in general, would be less harmed from knowing that minors were watching a film considered harmful by the authorities in the private classroom or at home, than by knowing that adults in public were watching the same film for educational purposes. Both presumptions reveal on their face how difficult it would be to support them, and how potentially irrational it would be for the Board to have to assert them.

Based on these arguments, the Board's refusal to allow the showing of the banned film for public educational purposes would in all likelihood be considered not reasonably justifiable in a democratic society. Thus, the argument could be made that the powers upon which the refusal was founded were disproportional and ultimately failed the test required of it to be considered a reasonably required limitation.

\section{SUMMARY}

Viewing censored footage is a reasonable method for adults to study film censorship; showing such footage is a reasonable method to present ideas relating to such studies. There is also a long tradition of academics sharing the findings of their studies with members of the public and to involve the public in the process of conducting inquiries (especially when their participation forms part of the research data of the inquiry). In the case study described, the academics involved in the organization of the study session on censorship had sound, academic reasons for wanting to use a banned film in their study session. The refusal of the Board to allow the use of the banned film at the study session thwarted the organizers' ability to achieve their purpose for wanting to use the banned film. Arguably, in terms of the first part of the test of constitutionality of the Board's action, this amounted to a hindrance of the academics' right to impart ideas free from interference. The powers the Board acted under would be regarded as disproportional because the actions taken by the Board could not be regarded as reasonably justifiable in a democratic society. 


\section{REFERENCES}

Foucault, M., \& Gordon, C. (1977).

Power/knowledge: Selected interviews and other writings, 1972-1977. New York: Pantheon Books.

Habermas, J. (1984-1987). The theory of communicative action. Boston: Beacon Press.

Mortimer, L. (2007, October). Censorship and the Bahamas Plays \& Films Control Board. Paper presented at the second study session, "Studying Censorship in The Bahamas: Examining the Bahamas Plays and Films Control Board", The College of The Bahamas, Nassau, Bahamas.

Swain, J. (2006, June 14). Film board challenged. The Nassau Guardian, p. A2

\section{Cases}

Council of Civil Service Unions v. Minister for the Civil Service [1984] 3 All ER 935

D’Aguiar v. Attorney-General (1962) 4 WIR 481

deFreitas v. Permanent Secretary of Agriculture Fisheries,. Lands and Housings and Others [1998] 3 LRC 62;

Hinds v. The Queen [1977] AC 195

Rangarajan v. Jagjivan Ram [1990] LRC (Const) 412

Re Ontario Film \& Video Appreciation Society and Ontario Board of Censors (1983) 147 D.L.R. (3d) 58; 41 O.R. (2d) 583 (Div. Ct.); 45 O.R. (2d) 80n (C.A)

Singh v Chinilall [1963] LRBG

\section{Statutes}

Penal Code, 1927, [CH. 84], (Bahamas)

The Constitution of The Commonwealth of The Bahamas, 1973.

Theatres and Cinemas Act, 1975, [CH. 384], (Bahamas)

Theatres and Cinemas (Censorship) Regulations, 1976, [CH. 384], (Bahamas) 